\section{SOI: $1.1 /$ TAS
International Scientific Journal $10.15863 / \mathrm{T}$ Theoretical \& Applied Science}

p-ISSN: 2308-4944 (print)

e-ISSN: 2409-0085 (online)

Year: 2017

Issue: 05

Volume: 49

Published: 3.05 .2017

http://T-Science.org

SECTION 23. Agriculture. Agronomy. The technique.
Makhamedkali Kenzhekhojayev

Candidate of Technical Sciences, docent Head of the department «Technology of food products, processing industries and biotechnology» M.Kh. Dulaty Taraz State University, Kazakhstan

Galymzhan Yussupov

Master of technical science Lecturer of the department «Technology of food products, processing industries and biotechnology» M.Kh. Dulaty Taraz State University, Kazakhstan yussupov.g@gmail.com

\title{
THE METHOD OF RECEIVING FERMENTED MILK BEVERAGES FROM GOAT MILK WITH SAFFRON
}

\begin{abstract}
The range of the products developed from goat milk, isn't so great now. Goat milk as raw materials is mastered only partially. However prospects of processing of goat milk are very wide that is connected with increase of the consumer demand, essential deficiency of cow milk and possibility of use of the available equipment. Development of the production technology of fermented milk beverages on the basis of goat milk will allow to expand the range of dairy products of dietary purpose of a domestic production. The technology of receiving fermented-milk beverages from goat milk with the saffron, having the general biological effect on an organism, on the intestines function, positively influencing its microbiocenosis and possessing immunomodulating action is developed that positively solves a problem of receiving drinks of treatment-and-prophylactic appointment.

Key words: goat milk, saffron.

Language: English

Citation: Kenzhekhojayev M, Yussupov G (2017) THE METHOD OF RECEIVING FERMENTED MILK BEVERAGES FROM GOAT MILK WITH SAFFRON. ISJ Theoretical \& Applied Science, 05 (49): 80-85. Soi: http://s-o-i.org/1.1/TAS-05-49-15 Doi: crossef https://dx.doi.org/10.15863/TAS.2017.05.49.15
\end{abstract}

\section{INTRODUCTION}

Dairy farming is one of the main sector in our republics' food production. It is $16 \%$ of all food production. 250 factories in Kazakhstan is producing 5-50 tons per day. It is one of the main sectors of our economics $[1,2]$.

Due to tasty and easy digestion of fermented milk products have medical and dietary characteristics and they are important to use everyday demand of organism $[3,4]$.

The quality and vitamin properties of milk and milk products depends on season. In winter the quality is lower than spring because of lack green grass in pasture. Furthermore, the vitamin properties of milk are lost during the separation, cooking, drying and etc. To solve this problem and we can enrich milk with biologically active substances [5].

Goat's milk-based food processing technology will help to normalize the microflora of the organism and increase the kinds of foods containing dietary significance.

Recently milk is produced with different fillers. Mostly with vegetable oils. It helps to enrich aminoacid and vitamin composition of the product. Using of non-traditional raw materials in milk products helps to increase biological and food value of the product $[6,7,8]$.
Therefore, it helps to develop our milk sector and it gives many opportunities to displace import products.

Nowadays many people cannot use cow's milk and each year their number is increasing. It means they should change their food ration. One of the products which can change cow's milk is goat's milk, because of its food value $[9,10]$. Goat milk is lower on lactose than cow milk and many people have allergic to lactose - goat milk can be a viable option.

Chemical composition of the goat milk is similar to some of the characteristics of cow's milk. But it has more oil, protein, mineral salts and dry substances, casein $75 \%$ [11,12].

The fat content of cow and goat milk is similar, the fat globules in goat milk are smaller, making it easier for your body digest. Once it reaches your stomach, the protein in goat milk forms a softer curd than cow milk - only about $2 \%$ of goat milk is curd, compared to about $10 \%$ in cow milk - helping your body digest it with less irritation than cow milk. Goat milk is also better tolerated by those with lactose issues and does not cause inflammation the way cow milk can. It is also a great option for children once they have moved past breastfeeding, as it contains fewer allergens than cow milk. Everyday for the 


\begin{tabular}{|c|c|c|c|c|c|c|}
\hline Impact Factor: & $\begin{array}{l}\text { ISRA (India) } \\
\text { ISI (Dubai, UAF } \\
\text { GIF (Australia) } \\
\text { JIF }\end{array}$ & $\begin{array}{l}=1.344 \\
=0.829 \\
=0.564 \\
=1.500\end{array}$ & $\begin{array}{l}\text { SIS (USA) } \\
\text { PИНЦ (Russia) } \\
\text { ESJI (KZ) } \\
\text { SJIF (Morocco) }\end{array}$ & $\begin{array}{l}=0.912 \\
=0.234 \\
=\mathbf{3 . 8 6 0} \\
=\mathbf{2 . 0 3 1}\end{array}$ & $\begin{array}{l}\text { ICV (Poland) } \\
\text { PIF (India) } \\
\text { IBI (India) }\end{array}$ & $\begin{array}{l}=6.630 \\
=1.940 \\
=4.260\end{array}$ \\
\hline
\end{tabular}

children it is enough to use goat's milk $30-40 \%$ less than cow milk.

Goat milk rich with protein, fat, vitamin and mineral substances. Comparing with cow milk, goat milk rich by calcium - $13 \%$, vitamin $\mathrm{B}_{6}-25 \%$, vitamin A - 47\%, potassium - 1,5 times, niacin - 3 times, copper - 4 times and selenium 1/3 times more. In goat milk does not have carotene acid, it is transformed to vitamin A in organism. Furthermore goat milk rich with vitamin $\mathrm{B}_{12}[13,14]$.
Recently to develop goat's milk production have two main factors:

1) for the high nutritional and medicinal properties;

2) cost-effective (to feed goat much more cheaper than cow). Nowadays goat farm is one of the fast growing production [15]. Table 1 shows goat milk characteristics.

Goat milk characteristics.

Table 1

\begin{tabular}{|c|l|c|}
\hline \multirow{2}{*}{ № } & \multicolumn{1}{|c|}{ Index, g / 100g } & Amount \\
\hline \multirow{4}{*}{1.} & Vitamins, mg & 0,3 \\
\cline { 2 - 3 } & Vitamin PP (nicotinic acid) & 0,0001 \\
\cline { 2 - 3 } & Vitamin A (retinol) & 0,036 \\
\cline { 2 - 3 } & Vitamin B1 (thiamine) & 0,001 \\
\cline { 2 - 3 } & Vitamin B2 (riboflavin) & 0,3 \\
\cline { 2 - 3 } & Vitamin B5 (pantothenic acid) & 0,05 \\
\cline { 2 - 3 } & Vitamin B6 (pyridoxine) & 0,012 \\
\cline { 2 - 3 } & Vitamin B9 (folic acid) & 1,81 \\
\cline { 2 - 3 } & Vitamin C (ascorbic acid) & 0,09 \\
\cline { 2 - 3 } & Vitamin E (tocopherol) & 143 \\
\hline \multirow{3}{*}{2.} & Macroelements, mg & 14 \\
\cline { 2 - 3 } & calcium & 46 \\
\cline { 2 - 3 } & Magnesium & 145 \\
\cline { 2 - 3 } & Sodium & 89 \\
\cline { 2 - 3 } & Potassium & \\
\cline { 2 - 3 } & Phosphorus & 0,01 \\
\hline \multirow{2}{*}{3.} & Trace elements, mg & - \\
\cline { 2 - 3 } & Iron & 0,02 \\
\cline { 2 - 3 } & Zinc & 0,016 \\
\cline { 2 - 3 } & Copper & \\
\cline { 2 - 3 } & Manganese & \\
\hline
\end{tabular}

To prepare fermented milk beverage from goat milk we have taken saffron. Saffron gives a good yellow color for our beverage. Saffron gives for our product high nutritional and biological value. It fills beverage with vitamins and mineral substances. As a result we can obtain biologically active substances, rich in dietary fiber. The price of the beverage would be available for everybody

Saffron is a plant (saffron - Latin Grocus). Saffron is a spice derived from the flower of Crocus sativus, commonly known as the "saffron crocus". Saffron crocus grows to $20-30 \mathrm{~cm}$ and bears up to four flowers, each with three vivid crimson stigmas, which are the distal end of a carpel. The nutrient content of saffron in a 100 gram amount shows richness of nutritional value across $B$ vitamins and dietary minerals [11].

In conclusion, adding vegetables to the diet, as well as the use of food as a phytophillers, improves assimilation of proteins, fats and mineral salts. Enhances secretory activity of digestive glands and significantly increases the biological properties of dairy products.

Material and methods. To achieve our results we have made our experiments in M.Kh. Dulaty Taraz State University, department "Technology of food products, processing industries and biotechnology". Experimental works made according with the following scheme.

Research objects:

- goat milk

- phytophillers

- $\quad$ saffron (water sediment)

- bacterial yeast

- Thermophilic streptococci TA 40 LYO 100 DCU (Danisco) (Danisco)

- Bifidobacterium lactis LYO 5 DCU-S

Research object (milk) was taken from («Азия» goat farm ) Zhambyl region.

On the first stage we defined chemical composition of raw material. 


\begin{tabular}{|c|c|c|c|c|c|c|}
\hline Impact Factor: & $\begin{array}{l}\text { ISRA (India) } \\
\text { ISI (Dubai, UAF } \\
\text { GIF (Australia) } \\
\text { JIF }\end{array}$ & $\begin{array}{l}=1.344 \\
=0.829 \\
=0.564 \\
=1.500\end{array}$ & $\begin{array}{l}\text { SIS (USA) } \\
\text { PИНЦ (Russia) } \\
\text { ESJI (KZ) } \\
\text { SJIF (Morocco) }\end{array}$ & $\begin{array}{l}=0.912 \\
=0.234 \\
=3.860 \\
=\mathbf{2 . 0 3 1}\end{array}$ & $\begin{array}{l}\text { ICV (Poland) } \\
\text { PIF (India) } \\
\text { IBI (India) }\end{array}$ & $\begin{array}{l}=6.630 \\
=1.940 \\
=4.260\end{array}$ \\
\hline
\end{tabular}

On the second stage to ferment goat milk we chosen bacteria composition. After this we made technology and recipe of fermented milk beverage.
On the last stage we defined fermented milk beverages' organoleptic, physicochemical, biochemical, vitamin, mineral and energy value.

Food and chemical composition of saffron.

Table 2

\begin{tabular}{|c|l|c|}
\hline № & \multicolumn{1}{|c|}{ Көрсеткіштері (100 гр) } & Саны \\
\hline 1 & Protein & 11,43 \\
\hline 2 & Fat & 5,85 \\
\hline 3 & Carbohydrates & 61,47 \\
\hline 4 & Dietary fiber & 3,9 \\
\hline 5 & Water & 11,9 \\
\hline 6 & Fatty acids & 1,586 \\
\hline 7 & Blossom & 5,45 \\
\hline 8 & Vitamin, mg & 1,46 \\
\hline \multirow{5}{*}{} & Vitamin PP (nicotinic acid) & 0,270 \\
\cline { 2 - 3 } & Vitamin A (retinol) & 0,115 \\
\cline { 2 - 3 } & Vitamin B1 (thiamine) & 0,627 \\
\cline { 2 - 3 } & Vitamin B2 (riboflavin) & - \\
\cline { 2 - 3 } & Vitamin B5 (pantothenic acid) & 1,01 \\
\cline { 2 - 3 } & Vitamin B6 (pyridoxine) & 0,093 \\
\cline { 2 - 3 } & Vitamin B9 (folic acid) & 0,8 \\
\cline { 2 - 3 } & Vitamin C (ascorbic acid) & - \\
\cline { 2 - 3 } & Vitamin E (tocopherol) & \\
\hline \multirow{4}{*}{9} & Macro elements, mg & 111,00 \\
\cline { 2 - 3 } & Calcium & 264,00 \\
\cline { 2 - 3 } & Magnesium & 148,00 \\
\cline { 2 - 3 } & Sodium & 1724 \\
\cline { 2 - 3 } & Potassium & 252,00 \\
\cline { 2 - 3 } & Phosphorus & 11,1 \\
\hline \multirow{5}{*}{10} & Microelements, mg & 1,09 \\
\cline { 2 - 3 } & Iron & 0,32 \\
\cline { 2 - 3 } & Zinc & 28,4 \\
\cline { 2 - 3 } & Copper, mg & 310 \\
\cline { 2 - 3 } & Manganese, mg & \\
\hline \multirow{5}{*}{11} & Energetic value, kcal & \\
\hline \multirow{3}{*}{} & & \\
\hline
\end{tabular}

Research methods.

During the research to define fat, protein, dry substances, titratable and active acidity, vitamin and mineral composition, organoleptic characteristics and physicochemical, biochemical, microbiological of finally product we have used standard methods.

ISO 5867-90, ISO 3626-73, ISO 25179-90 with this method we have defined composition of fat, moisture, dry substances, hydrocarbon and protein content;

- We have defined active acidity $\mathrm{pH}$ meter on $\mathrm{pH}-121$ at range from 4 to 9 with electrometer method ISO 26781-85;

- Titratable acidity defined with ISO 3624-92;

- Viscosity determined by Ostwald viscometer;

- Organoleptical characteristics of final product have been evaluated by 5 point scale. During the control has been evaluated taste, smell, density, appearance of the product;
- Choosing of physical-chemical sample of milk and raw has been carried out by ISO 26809-86, microbiological sample by ISO 9225-84.

Research physical-chemical, biochemical and microbiological indicators of goat milk. In this work we have taken into account hypo-allergenic and biological properties of goat milk.

Goat milk protein forms a softer curd ( the term given to the protein clumps that are formed by the action of your stomach acid on the protein), which makes the protein more easily and rapidly digestible. Goat's milk have advantages when it comes to allergies. Goat's milk contains only trace of an allergic casein protein, alpha-S1, found in cow's milk. People who have allergic to cow's milk can change them with goat's milk.

To milk processing we have been used modern technology and ozonized in TR-YCA unit.

To research we have taken $10-15 \mathrm{ml}$ morning goat milk ozonized in $140 \mathrm{mg} / \mathrm{m}^{3}$ the concentration 


\begin{tabular}{|c|c|c|c|c|c|c|}
\hline Impact Factor: & $\begin{array}{l}\text { ISRA (India) } \\
\text { ISI (Dubai, UAE } \\
\text { GIF (Australia) } \\
\text { JIF }\end{array}$ & $\begin{array}{l}=1.344 \\
=0.829 \\
=0.564 \\
=1.500\end{array}$ & $\begin{array}{l}\text { SIS (USA) } \\
\text { PИНЦ (Russia) } \\
\text { ESJI (KZ) } \\
\text { SJIF (Morocco) }\end{array}$ & $\begin{array}{l}=0.912 \\
=0.234 \\
=3.860 \\
=\mathbf{2 . 0 3 1}\end{array}$ & $\begin{array}{l}\text { ICV (Poland) } \\
\text { PIF (India) } \\
\text { IBI (India) }\end{array}$ & $\begin{array}{l}=6.630 \\
=1.940 \\
=4.260\end{array}$ \\
\hline
\end{tabular}

of ozone. Physical-chemical indicators of ozonized

goat milk is shown on table 2 .

Table 3

Physico-chemical characteristics of goat milk.

\begin{tabular}{|c|l|c|c|}
\hline № & \multicolumn{1}{|c|}{ Indicators, $\Gamma / 100 \Gamma$} & goat milk & Ozonized goat milk \\
\hline 1 & $20^{0} \mathrm{C}$, density, $\mathrm{g} / \mathrm{cm}^{3}$ & 1,031 & 1,033 \\
\hline 2 & ${ }^{0} \mathrm{~T}$, titrated acidity & 17,3 & 16,8 \\
\hline 3 & $\mathrm{pH}$, active acidity & 6,69 & 6,71 \\
\hline 4 & Пa·c, viscosity & 0,0178 & 0,0177 \\
\hline
\end{tabular}

As shown in table 3 titrated acidity ozonized milk increases by $0,5^{0} \mathrm{~T}$ and the viscosity is reduced by $0,56 \%$.

Table 4

Biochemical parameters of goat milk.

\begin{tabular}{|c|l|c|c|}
\hline № & \multicolumn{1}{|c|}{ Indicators, $\mathrm{g} / 100 \mathrm{~g}$} & goat milk & ozonized goat milk \\
\hline 1 & the mass fraction of moisture, \% & $86,98 \pm 0,01$ & $86,92 \pm 0,01$ \\
\hline 2 & the mass fraction of of dry substances, \% & $13,02 \pm 0,01$ & $13,08 \pm 0,01$ \\
\hline 3 & the mass fraction of fat, \% & $4,34 \pm 0,01$ & $4,37 \pm 0,01$ \\
\hline 4 & the mass fraction of protein, \% & $3,72 \pm 0,01$ & $3,73 \pm 0,01$ \\
\hline 5 & the mass fraction of lactose, \% & $4,17 \pm 0,02$ & $4,18 \pm 0,02$ \\
\hline 6 & the mass fraction of of wood ash, \% & $0,79 \pm 0,01$ & $0,8 \pm 0,01$ \\
\hline 7 & Energy value, kJ & 64,21 & 64,56 \\
\hline
\end{tabular}

As shown in table 3, after ozonation protein increased by $26 \%$ and Energy value $-0,54 \%$.

Research organoleptic properties of fermented milk beverages prepared by goat milk. In finished fermented milk beverages have been researched organoleptic, physical-chemical and microbiological properties.
Organoleptic characteristics of fermented milk product on the basis of goat milk are shown on table - 5. Sample №1 beverage - fermented milk beverage have been made on goat milk; sample №2 beverage - fermented milk beverage have been made on goat milk and saffron.

Organoleptic characteristics of fermented milk product made from goat's milk.

Table 5

\begin{tabular}{|c|c|c|c|c|}
\hline № & Mixture, \% & $\begin{array}{c}\text { Appearance and } \\
\text { consistency }\end{array}$ & Taste & Smell \\
\hline 1 & №1 drink & $\begin{array}{c}\text { uniformly white color } \\
\text { uniform consistency, } \\
\text { dense clot }\end{array}$ & $\begin{array}{c}\text { with a taste of } \\
\text { goat's milk }\end{array}$ & $\begin{array}{c}\text { free from foreign } \\
\text { smell, pure dairy }\end{array}$ \\
\hline 2 & №2 drink & $\begin{array}{c}\text { color homogeneous, gray- } \\
\text { purple, uniform } \\
\text { consistency, dense clot }\end{array}$ & $\begin{array}{c}\text { dairy, without the } \\
\text { taste of goat's milk }\end{array}$ & $\begin{array}{c}\text { free from foreign } \\
\text { smell, pure dairy }\end{array}$ \\
\hline
\end{tabular}

Organoleptical characteristics of final product have been evaluated by 5 point scale. During the control has been evaluated taste, smell, density, appearance of the product.

Physico-chemical characteristics of fermented milk product on the basis of goat milk are shown on table - 6. Sample №1 beverage - fermented milk beverage have been made on goat milk; sample №2 beverage - fermented milk beverage have been made on goat milk and saffron. 


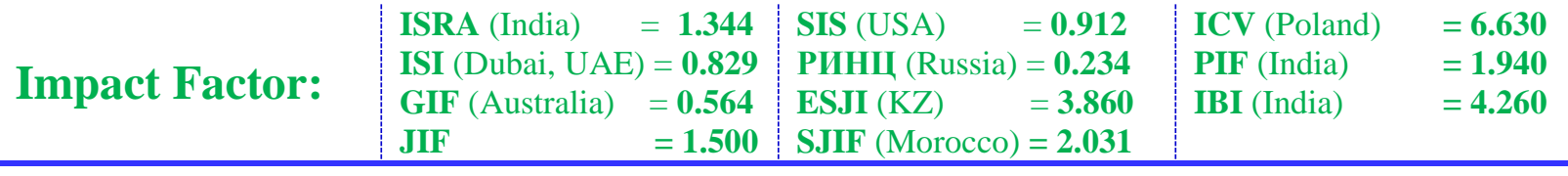

Table 6

Physico-chemical and biochemical indicators of fermented milk beverages on the basis of goat milk.

\begin{tabular}{|c|l|c|c|}
\hline № & \multicolumn{1}{|c|}{ Indicators, g / 100g } & №1 drink & №2 drink \\
\hline 1 & the mass fraction of moisture, \% & $86,95 \pm 0,01$ & $86,93 \pm 0,01$ \\
\hline 2 & the mass fraction of of dry substances, \% & $13,05 \pm 0,01$ & $13,07 \pm 0,01$ \\
\hline 3 & the mass fraction of fat, \% & $3,23 \pm 0,01$ & $3,24 \pm 0,01$ \\
\hline 4 & the mass fraction of protein, \% & $5,13 \pm 0,01$ & $5,15 \pm 0,01$ \\
\hline 5 & the mass fraction of lactose, \% & $3,89 \pm 0,01$ & $3,87 \pm 0,01$ \\
\hline 6 & the mass fraction of of wood ash, \% & $0,8 \pm 0,01$ & $0,81 \pm 0,01$ \\
\hline 7 & ${ }^{0}$ T, titrated acidity & 87 & 94 \\
\hline 8 & pH, active acidity & 4,63 & 4,28 \\
\hline 9 & energetic value of 100 grams of milk, calories & 64,17 & 64,27 \\
\hline 10 & energetic value of 100 g milk kJ & 58,6 & 58,7 \\
\hline
\end{tabular}

In table 6 showing amount of protein increased in sample №2. In these fermented milk beverages protein content increased 5,15\% and 5,2\%.

In sample №2 dry substances and wood ash increased a little bit.

In sample №2 titrated acidity increased to $7^{0} \mathrm{~T}$ and $10,5^{\circ} \mathrm{T}$.

Active acidity of fermented milk beverages is decreased.

In sample №2 energetic value increased to $0,15 \%$ and $0,6 \%$.

Therefore, adding saffron to ozonized goat milk can increase fermented milk beverages' energetic value.

\section{Conclusion}

Physico-chemical and microbiological characteristics of goat milk is increased. For example protein $0,26 \%$, titrated milk acidity $-0,5^{\circ} \mathrm{T}$ and energetic value is increased and it has been proven by research work.

The technology of receiving fermented milk beverages on the basis of goat milk with the phytofillers, having the general biological effect on an organism, on the intestines function, positively influencing its microbiocenosis and possessing immunomodulating action is developed that positively solves a problem of receiving drinks of treatment-and-prophylactic appointment.

\section{References:}

1. (2001) Sel'skoe, lesnoe i rybnoe hozyistvo Kazakshtana //Statisticheskii sbornik. Almaty. 2001.

2. Urazova RS (2005) Effectivnost' piwevoi promyshlennosti // Piwevaya i pererabatyvaiushay promyshlennost' Kazakhstana. - №3. - p. 4-5.

3. Shidlovskaya VP, et al. (1996) vliynie zakvasok molochnokislyh bakterii na soderjanie nitratov i nitritov $\mathrm{v}$ kislomolochnyh produktah i tvoroge. // Molochnaya promshlennost'. - 1996. - №6. p.26-25.

4. Stenfel'd ET, Shamanova ZI (2000) Bioproducty - producty budushego // Molochnaya promyshlennost'. - 2000. -№11.p. 20-21.

5. Delikatnaya IO, Bobrysheva SN (2004) Sovremennye tendencii primeneniy dobavok $\mathrm{v}$ pishevoi promyshlennosti. Bellorusskii specializirovannyi jurnal "Tehnologii pererabotki i upakovki". - №2. Available: http://real-press.com/article.php?aid=262.

6. (2000) Pishevay i pererabatyvaushay promyshlennost' Kazakhstana. Infromburo SPPPK RK, Nov.21, 2000.

7. Kunijev SM, Shuvaev VA (2004) Novye tehnologii $\mathrm{v}$ proizvodstve molochnyh produktov, M. DeLi pring, 2004.

8. Kunizhev SM, Andrusenko SF (2003) Sovremennye podhody $\mathrm{k}$ biotehnologii kompleksnoi pererabotki koz'ego moloka // Sbornik nauchnyh trudov posvyshennyi 80-letiu so dny rojdeniy N.N. Lipatov. - GNU VNIMI. M. - p. 103-111.

9. Ostroumova TL, Fridenberg GV, Volkova LG (2005) Koz'e moloo - natural'nay formula zdorov'y. // Molochnay promyshlnnost'. - № 8. - 2005. - p. 69-70.

10. Pelevina GA (2010) Sravnitel'nay harakteristika korov'ego i koz'ego moloka // Vestnik 
\begin{tabular}{l|lrl|l|ll} 
& ISRA (India) & $=\mathbf{1 . 3 4 4}$ & SIS (USA) & $=\mathbf{0 . 9 1 2}$ & ICV (Poland) & $=\mathbf{6 . 6 3 0}$ \\
Impact Factor: & ISI (Dubai, UAE) $=\mathbf{0 . 8 2 9}$ & PUHL (Russia) $=\mathbf{0 . 2 3 4}$ & PIF (India) & $=\mathbf{1 . 9 4 0}$ \\
& GIF (Australia) & $\mathbf{0 . 5 6 4}$ & ESJI (KZ) & $=3.860$ & IBI (India) & $=\mathbf{4 . 2 6 0}$ \\
& JIF & $=\mathbf{1 . 5 0 0}$ & SJIF (Morocco) & $=\mathbf{2 . 0 3 1}$ & & \\
\hline
\end{tabular}

Voronejskogo gosudarstvennogo agrarnogo universiteta. - № 4 (27). -p. 83-86.

11. Suunchev OA, Voblikova TV (2006) Osobennosti proizvodstva koz'ih syrov //Pererabotka moloka/ - № 6. - p. 11-14.

12. Merkusheva IN, Petrichenko SP, Kojuhova MA (2005) Peshevaya i biologicheskaya cennost' koz'ego moloka. // Izvestiy VUZov. Pishevaya tenologiy. - № 2-3. - p. 44-45.
13. Kuznecova TA (2003) A koz'e moloko luchshe / T.A. Kuznecova // Vse o moloke. - № 3. - p. 31.

14. Edwardes, Charlotte (2005) "Fresh Goat's Milk for Infants: Myths and Realities - A Review". London: DailyTelegraph. Retrieved 14, July, 2010.

15. Aleksadrovskay ES (2004) Antioksidantnye svoistva naptikov na plodoovoshnoi osnove spryno-aromaticheskimi travami. - № 4. - p. 8283. 